\title{
Synthesis and Characterization of New Schiff Bases Formed by Condensation of 2,9-Phenathroline-1,10-dialdehyde with Sulfur-Containing Amines
}

\author{
Md. Arifuzzaman', Mohammad R. Karim ${ }^{1 *}$, Tasneem A. Siddiquee ${ }^{1}$, \\ Aminul H. Mirza' ${ }^{2}$ Mohamad A. Ali ${ }^{2}$ \\ ${ }^{1}$ Department of Chemistry, Tennessee State University, Nashville, USA \\ ${ }^{2}$ Faculty of Science, University of Brunei Darussalam, Bandar Seri Begawan, Brunei \\ Email: ${ }^{*}$ mkarim@tnstate.edu
}

Received February 12, 2013; revised March 15, 2013; accepted March 18, 2013

\begin{abstract}
Four new Schiff bases of 1,10-phenanthroline-2,9-dicarboxaldehyde with sulfur-containing amines such as 2-mercaptoaniline, S-alkyl/aryl dithiocarbazates and thiosemicarbazide have been synthesized and characterized by spectroscopic and X-ray crystallographic techniques. A comparative study of the methods of synthesis has been made using both traditional and microwave techniques. A significant reduction in reaction time has been observed when the microwave method was used. In some of the reactions, the yields also increased significantly.
\end{abstract}

Keywords: Phenanthroline; Schiff Base; Dithiocarbazide; Sulfur-Containing; Antibaterial

\section{Introduction}

There is a continuing interest in the design and synthesis of molecules that efficiently bind to DNA and cleave it. In particular, the study of organic chelating agents containing nitrogen and sulfur as the donor atoms and their metal complexes has become a subject of intensive investigation. In this regard, the use of bidentate N,N chelating agents such as 1,10-phenanthroline (phen) has played an important role in synthetic and medicinal chemistry [1]. 1,10-Phenanthroline has also been used extensively as a ligand in both analytical and preparative coordination chemistry as well as in the preparation of many mixed-ligand complexes [2]. 1,10-Phenanthroline and ligands derived from it as well as some of their metal complexes have also been found to be widely used in areas such as molecular catalysis, solar energy conversion, calorimetric analysis, herbicides, molecular recognition, self-assembly, antineoplastic agents, and nucleic acid probes [3]. It has been found that Schiff bases formed by condensation of S-alkyl/aryl esters of dithiocarbazaic acid with heterocyclic aldehydes and ketones contain both "hard" nitrogen and "soft" sulfur donor atoms [4]. Consequently, they are capable of forming stable complexes with a wide vriety of metal ions, some of

"Corresponding author. which have also been found to exhibit interesting physico-chemical properties and potentially useful chemotherapeutic properties [5].

It has also been reported that polymeric metal complexes of 1,10-phenanthroline-based liands containing bithiazole rings exhibit significant magnetic properties [6-10]. Since organic and polymeric magnets offer advantages over traditional magnets because of the diversity of their structures, low density, low magnetic loss and process of preparation without metallurgy at high temperature, studies involving the synthesis of Schiff bases using 1,10-phenanthroline-2,9-dicarboxaldehyde and sulfur-containing primary amines deserve more attention. We, therefore, report here the synthesis and characterization of four new Schiff bases formed from 1,10-phenanthroline-2,9-dialdehyde and some sulfurcontaining amines.

\section{General Methods and Procedures}

HPLC grade solvents were used in all the reactions. The conventional method $(\mathrm{C})$ of synthesis involves refluxing the reaction mixture for $1-3$ hours followed by filtration of the solid products using suction filtration.

Conditions for the Microwave method (M) of reaction are as follows: Temp $=75^{\circ} \mathrm{C}$ for ethanol and $70^{\circ} \mathrm{C}$ for 
methanol; Reaction Time $=15$ minutes, Pressure $=250$ (psi), Power $=200(\mathrm{~W})$.

In all the reactions, 2 - 3 drops of conc. sulfuric acid were used. The solid product that had formed was filtered off using suction filtration. All NMR data were recorded on a $300 \mathrm{MHz}$ Varian NMR Spectrometry. Mass Spectra were obtained on a Varian LC-MS with ESI.

\section{Synthesis}

We have previously reported the X-ray structure of the solvated 2,9-bis(aminothiophenol)-1,10-phenanthroline that contained two molecules of dichloromethane as lattice solvent [11]. We now report here the synthesis and crystal structure of the dichloromethane-free 2,9-bis (aminothiophenol)-1,10-phenanthroline together with the synthesis of three new Schiff bases formed by condensation of the dialdehyde with amines containing thione or thiol sulfur donor atoms in their backbones. All the compounds have been structurally characterized by spectroscopic as well as X-ray diffraction techniques.

\subsection{Synthesis of 1,10-Phenanthroline-2,9- di-carboxaldehyde from 2,9-Dimethyl-1,10- phenanthroline Hemi-Hydrate}

1,10-phenanthroline-2,9-dicarboxaldehyde was synthesized from 2,9-dimethyl-1,10-phenanthroline hemi-hydrate following a previously reported procedure [12-14]. The reaction was also carried out under microwave conditions. The yield of the compound was found to be the same as that obtained by the traditional method. However, in the microwave method, the product formed in $10 \mathrm{~min}$ compared to 4 hours of refluxing time required in the traditional method. The crude product was recrystallized from hot acetone and dried under vacuum to give the pure compound [Y: 86\%] (Scheme 1).

\subsection{Synthesis of 2,9-Di-(benzo[d]thiazol-2-yl)- 1,10-phenanthroline from 1,10- Phenanthroline-2,9-dicarboxaldehyde and 2-Mercaptoaniline}

2-Mercaptoaniline (4 equivalents) was added to a solution of 1,10-phenanthroline-2,9-di-carboxal-dehyde (1 equivalent) in absolute ethanol $(30 \mathrm{~mL})$ containing $2-3$ drops of conc. sulfuric acid. The solution was refluxed

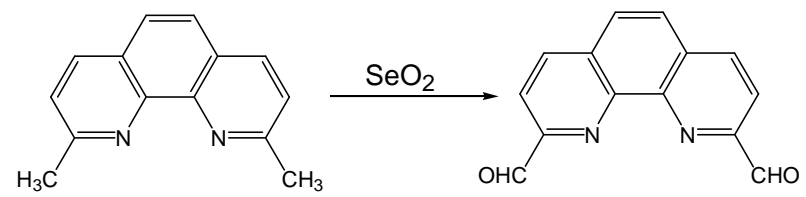

Scheme 1. Synthesis of 1,10-phenanthroline-2,9-di-carboxaldehyde. for $3 \mathrm{hr}$ in the conventional method and irradiated for 15 minutes in the microwave method. The reaction mixture was then allowed to cool whereupon the product that had formed was filtered off, washed with ethanol and dried under vacuum. Recrystallization of the crude product from dichloromethane afforded white crystals. Table 1 shows different reaction conditions and percent yields. IR: $v\left(\mathrm{~cm}^{-1}\right)$ 3100, $3080(\mathrm{CH}$ aromatic), $1618(\mathrm{C}=\mathrm{C}$ aromatic), $1580(\mathrm{C}=\mathrm{N}), 1551(\mathrm{C}=\mathrm{C}) .{ }^{1} \mathrm{H}-\mathrm{NMR}\left(\mathrm{DMSO}-\mathrm{d}_{6}\right)$ : $\delta_{\mathrm{H}}=8.75(\mathrm{~d}, \mathrm{~J}=8.4 \mathrm{~Hz}, 8-\mathrm{H}, 3-\mathrm{H}), 8.70(\mathrm{~d}, \mathrm{~J}=8.4 \mathrm{~Hz}$, H-4, H-7), 7.30 (d, j = 7.2 H-18, H-18', 21, 21'), 8.17 (s, H-5, 6), 7.60 (m, H-19, H-19', H-20, H-20'). ${ }^{13}$ C-NMR (DMSO-d 6 , ppm): $\delta_{\mathrm{C}} 170,155,152,147,139,137,130$, $128,127,126,124,123,120$. LC-MS (m/z, M $\left.)^{+}\right): 451(\mathrm{M}$ $\left.+5 \mathrm{H}^{+}\right), 450\left(\mathrm{M}+4 \mathrm{H}^{+}\right), 449\left(\mathrm{M}+3 \mathrm{H}^{+}\right), 447\left(\mathrm{M}+\mathrm{H}^{+}\right)$, $446\left(\mathrm{M}^{+}\right), 417\left(\mathrm{M}+3 \mathrm{H}^{+}-\mathrm{S}\right), 418\left(\mathrm{M}+4 \mathrm{H}^{+}-\mathrm{S}\right), 372(\mathrm{M}+$ $\left.2 \mathrm{H}^{+}-\mathrm{C}_{6} \mathrm{H}_{4}\right), 359\left(\mathrm{M}+3 \mathrm{H}^{+}-\mathrm{C}_{6} \mathrm{H}_{4} \mathrm{~N}\right), 358\left(\mathrm{M}+2 \mathrm{H}^{+}-\right.$ $\left.\mathrm{C}_{6} \mathrm{H}_{4} \mathrm{~N}\right), 344\left(\mathrm{M}^{+}-\mathrm{C}_{7} \mathrm{H}_{4} \mathrm{~N}\right), 328\left(\mathrm{M}+2 \mathrm{H}^{+}-\mathrm{C}_{6} \mathrm{H}_{4}-\mathrm{CS}\right), 314$ $\left(\mathrm{M}+2 \mathrm{H}^{+}-\mathrm{C}_{6} \mathrm{H}_{4} \mathrm{~N}-\mathrm{N}\right)$ (Scheme 2).

\subsection{Synthesis of (2,2')-Dimethyl 2,2'-(1,10-}

Phenanthroline-2,9-diyl)bis(methan-1-yl-1ylidene)-bis(hydrazinecarbodithioate) (2) from 1,10-Phenanthroline-2,9dicarboxaldehyde and S-Methyldithiocarbazate (SMDTC)

SMDTC was prepared following the procedure of Tarafder et al. [15] (Scheme 3).

Table 1. Reaction conditions and percent yields of the schiff base-1.

\begin{tabular}{cccc}
\hline Method $^{\mathrm{a}}$ & Solvent & Time & \% Yield \\
\hline $\mathrm{C}$ & EtOH & 3 hours & 67 \\
$\mathrm{C}$ & $\mathrm{MeOH}$ & 3 hours & 54 \\
$\mathrm{M}$ & $\mathrm{EtOH}$ & $15 \mathrm{~min}$ & 78 \\
$\mathrm{M}$ & $\mathrm{MeOH}$ & $15 \mathrm{~min}$ & 50 \\
\hline
\end{tabular}

C-Conventional; M-Microwave.

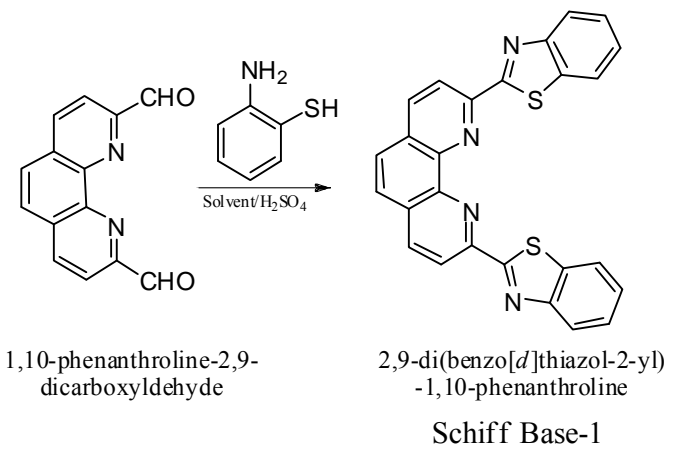

Scheme 2. 2,9-di-(benzo[d]thiazol-2-yl)-1,10-phenanthroline shiff base. 


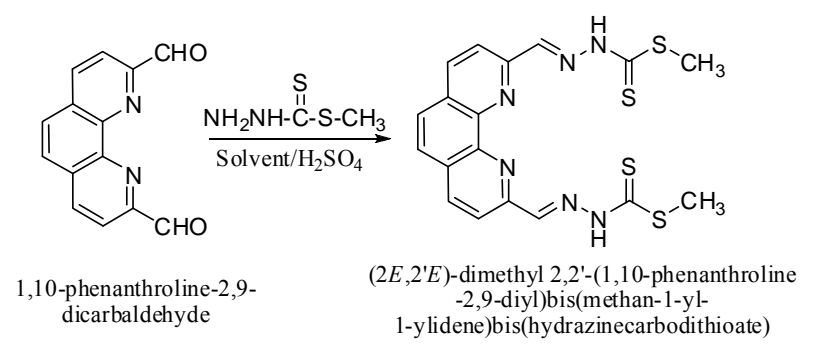

Schiff Base-2

Scheme 3. Synthesis of (2,2')-dimethyl 2,2'-(1,10-phenanthroline-2,9-diyl)bis(methan-1-yl-1-ylidene)-bis(hydrazineca rbodithioate) schiff base.

SMDTC (0.12 g, $0.99 \mathrm{mmol})$ was added to a solution of 1,10-phenanthroline-2,9-dicarboxaldehyde ( $0.09 \mathrm{~g}, 0.33$ $\mathrm{mmol}$ ) in $30 \mathrm{~mL}$ absolute ethanol containing 2 drops of conc. sulfuric acid. The solution was refluxed for $2 \mathrm{hr}$ and then allowed to cool to room temperature. The solid product that had formed was filtered off, washed with ethanol and dried under vacuum. The crude product was recrystallized from dimethylsulfoxide to obtain white crystals suitable for X-ray diffraction. Yields are shown in Table 2 for various reaction conditions and solvents. The highest yields were obtained using methanol as the solvent: IR: $v\left(\mathrm{~cm}^{-1}\right) .3200(\mathrm{NH}), 3200(\mathrm{~N}-\mathrm{H}), 3100$, $2900(\mathrm{CH}$ aromatic and aliphatic), $1580(\mathrm{C}=\mathrm{N}), 1500$, $1600\left(\mathrm{C}=\mathrm{C}\right.$, aromatic), $1050(\mathrm{C}=\mathrm{S}) .{ }^{1} \mathrm{H}-\mathrm{NMR}$ (DMSO-d $\mathrm{d}_{6}$, ppm): $\delta_{\mathrm{H}} 13.71(\mathrm{~s}, 2 \mathrm{NH}), 8.28(\mathrm{~d}, \mathrm{~J}=8.7 \mathrm{~Hz}, 2 \mathrm{H}), 8.58$ $(\mathrm{d}, \mathrm{J}=8.7 \mathrm{~Hz}, 2 \mathrm{H}), 8.60$ (s, 2H), 8.07 (s, 2H), 2.01 (s, 6H). ${ }^{13} \mathrm{C}-\mathrm{NMR}$ (DMSO-d 6 , ppm): $\delta_{\mathrm{C}} 206,199,146,139$, 129, 127, 126, 119, 30. LC-MS (m/z, M $\left.{ }^{+}\right): 446(\mathrm{M}+$ $\left.2 \mathrm{H}^{+}\right), 445\left(\mathrm{M}+\mathrm{H}^{+}\right), 444\left(\mathrm{M}^{+}\right), 397\left(\mathrm{M}+\mathrm{H}^{+}-\mathrm{CH}_{3} \mathrm{SH}\right)$, $386\left(\mathrm{M}-\mathrm{C}_{2} \mathrm{H}_{2} \mathrm{~S}\right), 346\left(\mathrm{M}+\mathrm{H}^{+}-2 \mathrm{CH}_{3} \mathrm{SH}\right), 266\left(\mathrm{M}+2 \mathrm{H}^{+}-\right.$ $2 \mathrm{C}_{2} \mathrm{H}_{2} \mathrm{~S}_{2}$ ) (Figure 1).

The results in Table 2 above indicate a significant increase in \% yield in the microwave method using methanol as a solvent.

\subsection{Synthesis of (2,2')-Benzyl 2,2'-(1,10- phenanthroline-2,9-diyl)bis(methan-1-yl-1- ylidene)-bis(hydrazinecarbodithioate) (3) from 1,10-Phenanthroline-2,9- dicarboxaldehyde and S-Benzyldithiocarbazate (SBDTC)}

SBDTC was prepared using a procedure described by Audrieth et al. in a similar synthesis [16]. SBDTC (0.198 $\mathrm{g}, 1.00 \mathrm{mmol})$ was added to a solution of 1,10-phenanthroline-2,9-dicarboxaldehyde $(0.12 \mathrm{~g}, 0.50 \mathrm{mmol})$ in 30 $\mathrm{mL}$ absolute ethanol followed by the addition of two drops of conc. sulfuric acid. The reaction mixture was refluxed for $3 \mathrm{~h}$, then left to cool to room temperature. The product that had formed was filtered off, washed with ethanol and dried in vacuum. White crystals of the compound were obtained by recrystallizing the crude product from dimethylsulfoxide. Yields in ethanol and methanol under different reaction conditions are given in the Table 3. Diffraction quality crystals for X-Ray structure determination were obtained by recrystallizing the compound from dimethylsulfoxide. IR: $v\left(\mathrm{~cm}^{-1}\right)$ : $3200(\mathrm{~N}-\mathrm{H}), 3029$ (=CH aromatic), 2900 (C-H aliphatic), $1572(\mathrm{C}=\mathrm{N}), 1500,1605(\mathrm{C}=\mathrm{C}), 1056(\mathrm{C}=\mathrm{S}) .{ }^{1} \mathrm{H}-\mathrm{NMR}$ (DMSO-d $6, \mathrm{ppm}): \delta_{\mathrm{H}} 13.80(\mathrm{~s}, 2 \mathrm{NH}), 8.63(\mathrm{~s}, 2 \mathrm{H}), 8.56$ $(\mathrm{d}, \mathrm{J}=8.5 \mathrm{~Hz}, 2 \mathrm{H}), 8.27(\mathrm{~d}, \mathrm{~J}=8.5 \mathrm{~Hz}, 2 \mathrm{H}), 8.08(\mathrm{~s}, 2 \mathrm{H})$, $7.48(\mathrm{~d}, \mathrm{~J}=7.1 \mathrm{~Hz}, 4 \mathrm{H}), 7.38(\mathrm{dd}, \mathrm{J}=7.1 \mathrm{~Hz}$ \& $7.2 \mathrm{~Hz}$, 4H), $7.33(\mathrm{~m}, 2 \mathrm{H}), 4.6(\mathrm{~s}, 2 \mathrm{H}) .{ }^{13} \mathrm{C}-\mathrm{NMR}$ (DMSO-d 6 , ppm): $\delta_{\mathrm{C}} 197,163,153,147,145,137,136,129,127$, 119, 56. LC-MS (m/z): $599\left(\mathrm{M}+3 \mathrm{H}^{+}\right), 598\left(\mathrm{M}+2 \mathrm{H}^{+}\right)$, $597\left(\mathrm{M}+\mathrm{H}^{+}\right), 596\left(\mathrm{M}^{+}\right), 474\left(\mathrm{M}+2 \mathrm{H}^{+}-\mathrm{PhCH}_{2} \mathrm{SH}\right), 473$ $\left(\mathrm{M}+\mathrm{H}^{+}-\mathrm{PhCH}_{2} \mathrm{SH}\right), 349\left(\mathrm{M}+\mathrm{H}^{+}-2 \mathrm{CH}_{3} \mathrm{SH}\right), 399(\mathrm{M}+$ $\left.3 \mathrm{H}^{+}-\mathrm{C}_{13} \mathrm{H}_{12} \mathrm{~S}\right), 350\left(\mathrm{M}+2 \mathrm{H}^{+}-2 \mathrm{PhCH}_{2} \mathrm{SH}\right), 321\left(\mathrm{M}+\mathrm{H}^{+}-\right.$ $\left.2 \mathrm{CH}_{3} \mathrm{SH}-\mathrm{N}_{2}\right), 293\left(\mathrm{M}+\mathrm{H}^{+}-2 \mathrm{CH}_{3} \mathrm{SH}-2 \mathrm{~N}_{2}\right)$ (Scheme 4 and Figure 2).

Table 2. Reaction conditions and percent yields for the synthesis of schiff base-2.

\begin{tabular}{cccc}
\hline Method & Solvent & Time & \% Yield \\
\hline $\mathrm{C}$ & EtOH & $2 \mathrm{hr}$ & 33 \\
$\mathrm{C}$ & $\mathrm{MeOH}$ & $1 \mathrm{hr}$ & 48 \\
$\mathrm{M}$ & $\mathrm{EtOH}$ & $15 \mathrm{~min}$ & 30 \\
$\mathrm{M}$ & $\mathrm{MeOH}$ & $15 \mathrm{~min}$ & 50 \\
\hline
\end{tabular}

Table 3. Reaction conditions and percent yields for the synthesis of schiff base- 3 .

\begin{tabular}{cccc}
\hline Method & Solvent & Time & \% Yield \\
\hline $\mathrm{C}$ & EtOH & $2 \mathrm{hr}$ & 57 \\
$\mathrm{C}$ & $\mathrm{MeOH}$ & $2 \mathrm{hr}$ & 62 \\
$\mathrm{M}$ & $\mathrm{EtOH}$ & $15 \mathrm{~min}$ & 60 \\
$\mathrm{M}$ & $\mathrm{MeOH}$ & $15 \mathrm{~min}$ & 94 \\
\hline
\end{tabular}

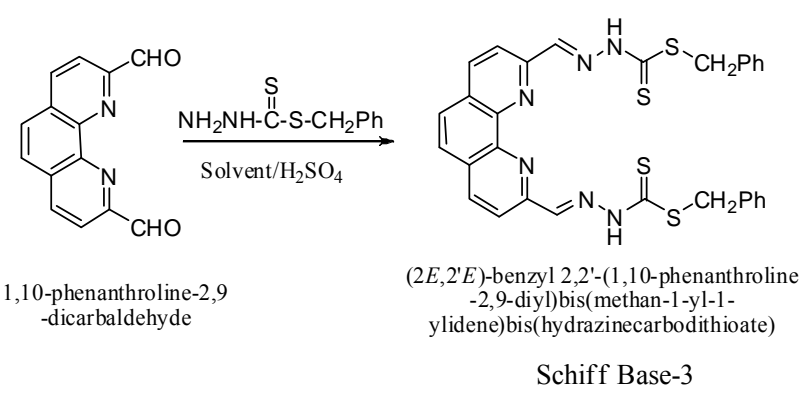

Scheme 4. Synthesis of (2,2')-benzyl 2,2'-(1,10-phenanthroline-2,9-diyl)bis(methan-1-yl-1-ylidene)-bis(hydrazineca rbodithioate) schiff base. 


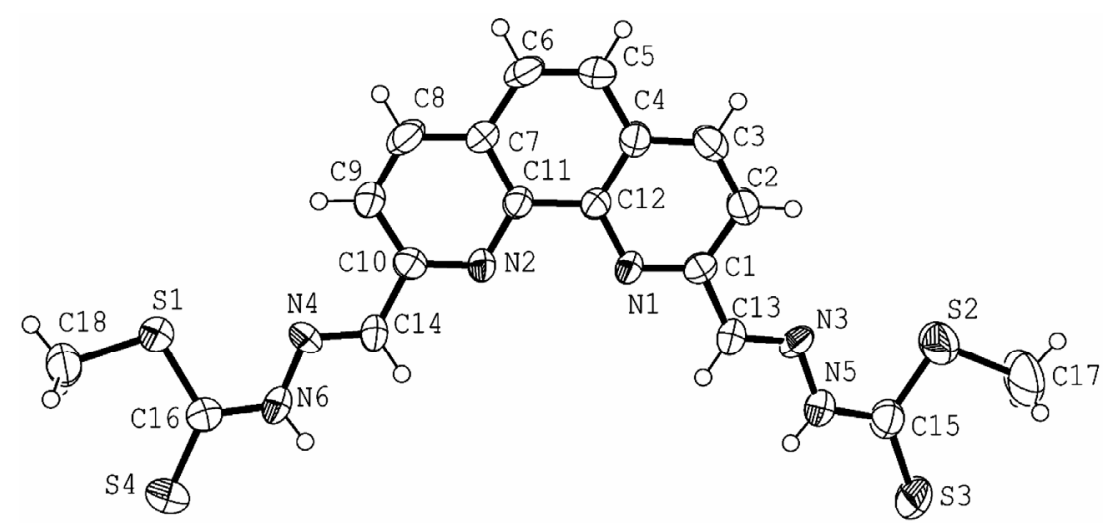

Figure 1. ORTEP diagram of (2,2')-dimethyl 2,2'-(1,10-phenanthroline-2,9-diyl)bis(methan-1-yl-1-ylidene)-bis(hydrazinecarbodithioate) (2). Solvent molecules not included for clarity.

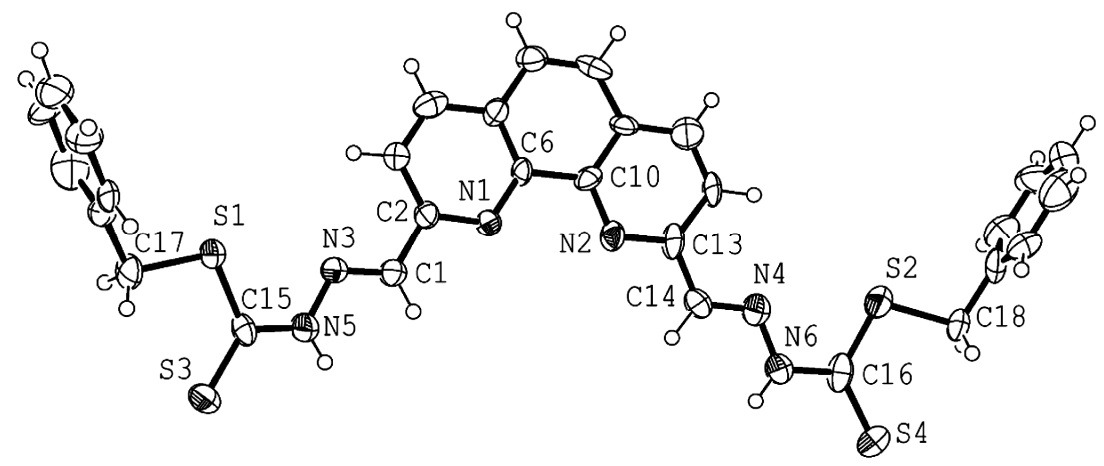

Figure 2. ORTEP diagram of (2,2')-benzyl 2,2'-(1,10-phenanthroline-2,9-diyl)bis(methan-1-yl-1-ylidene)-bis(hydrazinecarbodithioate) (3). Solvent molecules not included for clarity.

\subsection{Synthesis of (2,2')-2,2'-(1,10-Phenanthroline- 2,9-diyl)bis(methan-1-yl-1-ylidene)bis- (hydrazinecarbodithioate (4)) from 1,10-Phenanthroline-2,9-dicarboxaldehyde and Thiosemicarbazate Scheme 5}

The compound was prepared using the same procedure as used for 4. Yields in ethanol and methanol under different reaction conditions are given in the Table 4. Thiosemicarbazide $(0.136 \mathrm{~g}, 1.5 \mathrm{mmol})$ was used instead of S-benzyldithiocazate. IR: $v\left(\mathrm{~cm}^{-1}\right): 3300,3250\left(\mathrm{NH}_{2}\right)$, $3153(=\mathrm{CH}), 1580(\mathrm{C}=\mathrm{N}), 1046(\mathrm{C}=\mathrm{S}) .{ }^{1} \mathrm{H}-\mathrm{NMR}$ (DMSO$\left.\mathrm{d}_{6}, \mathrm{ppm}\right): \delta_{\mathrm{H}} 12.02(\mathrm{~s}, 2 \mathrm{NH}), 8.78(\mathrm{~d}, \mathrm{~J}=8.2 \mathrm{~Hz}, 2 \mathrm{H})$, $8.60(\mathrm{~d}, \mathrm{~J}=8.2 \mathrm{~Hz}, 2 \mathrm{H}), 8.50(\mathrm{~s}, 2 \mathrm{H}), 8.08(\mathrm{~s}, 2 \mathrm{H})$. ${ }^{13} \mathrm{C}-\mathrm{NMR}$ (DMSO-d $\left.\mathrm{d}, \mathrm{ppm}\right): \delta_{\mathrm{C}} 178,154,151,145,140$, 137, 128, 120. LC-MS (m/z): $384\left(\mathrm{M}+2 \mathrm{H}^{+}\right), 383(\mathrm{M}+$ $\left.\mathrm{H}^{+}\right), 382\left(\mathrm{M}^{+}\right), 366\left(\mathrm{M}+\mathrm{H}^{+}-\mathrm{NH}_{3}\right), 354\left(\mathrm{M}+2 \mathrm{H}^{+}-\mathrm{N}_{2} \mathrm{H}_{2}\right)$, $349\left(\mathrm{M}+\mathrm{H}^{+}-2 \mathrm{NH}_{3}\right)$.

Methanol was found to be a better solvent in the synthesis of the Schiff base in which thiosemicarbazide was used as one of the reactants. Both microwave and conventional methods produced the same \% yield. However, microwave conditions used only 15 minutes.

$\mathrm{X}$-ray structures of the Schiff bases show that the azomethine nitrogen atoms in the molecules are trans to

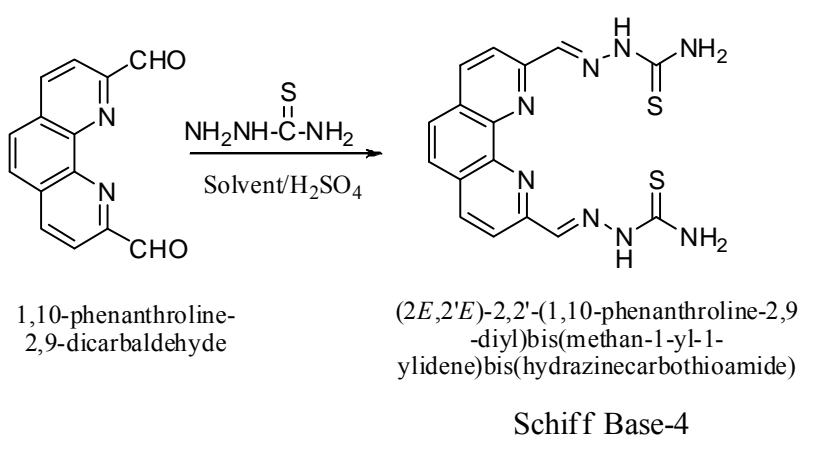

Scheme 5. Synthesis of (2,2')-2,2'-(1,10-phenanthroline-2,9diyl)bis(methan-1-yl-1-ylidene)bis-(hydrazinecarbodithioate) schiff base.

Table 4. Reaction conditions and percent yields for the synthesis of schiff base- 4 .

\begin{tabular}{cccc}
\hline Method & Solvent & Time & \% Yield \\
\hline $\mathrm{C}$ & EtOH & $3 \mathrm{hr}$ & 69 \\
$\mathrm{C}$ & $\mathrm{MeOH}$ & $1 \mathrm{hr}$ & 83 \\
$\mathrm{M}$ & $\mathrm{EtOH}$ & $15 \mathrm{~min}$ & 85 \\
$\mathrm{M}$ & $\mathrm{MeOH}$ & $15 \mathrm{~min}$ & 85 \\
\hline
\end{tabular}


the phenanthroline ring nitrogen atoms but the thione sulfur atoms are cis to them. In this configuration, the Schiff bases cannot act as hexadentate chelating agents using the two phenanthroline ring nitrogen atoms, the two azomethine nitrogen atoms and the two thione sulfur atoms. However, in solution, rotations about the $\mathrm{C}-\mathrm{C}$ and $\mathrm{N}-\mathrm{N}$ bonds of the hydrazinic side chains are possible and in this way, all the six donor atoms can take up positions suitable for coordination with a metal ion.

\section{X-Ray Structure}

Crystals of the Schiff bases 2 and $\mathbf{3}$ were grown from DMSO. Crystals of dimensions $0.36 \times 0.21 \times 0.12 \mathrm{~mm}^{3}$ and $0.22 \times 0.11 \times 0.03 \mathrm{~mm}^{3}$ for 2 and 3 , respectively were mounted on a MiTeGen loop with Apiezon grease at ambient temperature. Diffraction study was done on a Rigaku XtaLab mini bench-top instrument. Data collection and data reduction was done with the software of the instrument "Crystal Clear" [17]. The radiation source was $\operatorname{MoK} \alpha(\lambda=0.71075 \AA)$. Schiff base 3 crystallized out of solution as platelets as can be seen from the crystal dimension, which had affect on data quality. Both the compounds were crystallized in a triclinic crystal system with P-1 space group. Unit cell dimensions (Schiff base 2): $\mathrm{a}=9.826$ (3) $\AA, \mathrm{b}=11.581$ (3) $\AA, \mathrm{c}=14.034$ (4) $\AA, \alpha$ $=107.671(8)^{\circ}, \beta=100.278(7)^{\circ}, \gamma=99.610(7)^{\circ}$ and Volume 1455.0 (7) $\AA 3$. Unit cell dimensions (Schiff base 3): $\mathrm{a}=11.841$ (5) $\AA, \mathrm{b}=12.204$ (5) $\AA, \mathrm{c}=15.361$ (6) $\AA$, $\alpha=80.986(6)^{\circ}, \beta=70.997(5)^{\circ}, \gamma=88.934(6)^{\circ}$ and Volume 2071.6 (15) $\AA 3$.

Structure Solution and Refinement: The structure was solved by direct methods [18] and expanded using Fourier techniques. The non-hydrogen atoms were refined anisotropically. Hydrogen atoms were refined using the riding model. The final cycle of full-matrix least-squares refinement on $\mathrm{F}^{2}$ was based on 3117 and 4187 observed reflections, 325 and 469 variable parameters for Schiff bases 2 and 3 respectively. Which converged with unweighted and weighted agreement factors of: R1 = 0.0358 and $\mathrm{wR} 2=0.0839$ for Schiff base 2 and $\mathrm{R} 1=$ $0.0988, \mathrm{wR} 2=0.2353$ for Schiff base 3. This was conducted using the program suite WINGX [18]. The compounds crystallized as solvates. Schiff base 2 had two DMSO molecules and Schiff base 3 had three DMSO solvent molecules per asymmetric unit. One of the DMSO molecules in Schiff base 2 was disordered with the sulfur atom occupying two sites each as the inversion of the other with site occupancy factors of 0.7 and 0.3 . The other DMSO molecule is located within the range of hydrogen bonding interaction with the $\mathrm{H} 5$ atom on N5 atom of the molecule for Schiff base 2. For Schiff base 3, two of the DMSO molecules are within the range of hydrogen bonding interaction with the hydrogen atoms on $\mathrm{N} 5$ and N6 atoms of the molecule.
Schiff base 2 .

\begin{tabular}{ccccc}
\hline $\mathrm{D}-\mathrm{H} \cdots \mathrm{A}$ & $\mathrm{D}-\mathrm{H}$ & $\mathrm{H} \cdots \mathrm{H}$ & $\mathrm{D} \cdots \mathrm{A}$ & $\mathrm{D}-\mathrm{H} \cdots \mathrm{A}$ \\
\hline $\mathrm{N}(9)$ & & & & \\
$\mathrm{H}(10)$ & 0.86 & 2.21 & $2.952(10)$ & $143.9(6)$ \\
$\mathrm{O}(32)$ & & & & \\
\hline
\end{tabular}

Schiff base 3.

\begin{tabular}{ccccc}
\hline D-H ${ }^{\cdots} \mathrm{A}$ & $\mathrm{D}-\mathrm{H}$ & $\mathrm{H} \cdots \mathrm{H}$ & $\mathrm{D} \cdots \mathrm{A}$ & $\mathrm{D}-\mathrm{H} \cdots \mathrm{A}$ \\
\hline $\mathrm{N}(5)$ & & & & \\
$\mathrm{H}(5)$ & 0.86 & 1.97 & $2.738(15)$ & $148.9(7)$ \\
$\mathrm{O}(45)$ & & & & \\
$\mathrm{N}(5)$ & & & & \\
$\mathrm{H}(6)$ & 0.86 & 1.96 & $2.753(12)$ & $152.5(8)$ \\
$\mathrm{O}(38)$ & & & & \\
\hline
\end{tabular}

\section{Conclusion}

Four new Schiff bases of 2,9-dimethyl-1,10-phenanthroline hemi-hydrate with sulfur-containing amines have been successfully synthesized. Significant reduction in reaction time has been observed when the CEM microwave technology was used. In some cases, methanol was found to be a better solvent than ethanol. However, reaction of the dialdehyde with 2-mercaptoaniline in $\mathrm{MeOH}$ did not lead to the formation of the cyclic product in high yield. Due to the higher polarity of $\mathrm{MeOH}$, the oxidative elimination of $\mathrm{H}_{2}$ was not favorable.

\section{Acknowledgements}

We thank the Department of Chemistry at Tennessee State University for providing the necessary support to carry out the research. We also thank the Department of Education, Title III funds for providing instrumental support.

\section{REFERENCES}

[1] P. G. Sammes and G. Yahioglu, "1,10-Phenanthroline: A Versatile Ligand," Chemical Society Reviews, Vol. 23, No. 5, 1994, pp. 327-334. doi:10.1039/cs9942300327

[2] J. Reedijk, "Comprehensive Coordination Chemistry," G. Wilkinson, R. D. Dillard and J. A. McCleverty, Eds., Pergamon, Oxford, 1987, Vol. 2, p. 73.

[3] Y. Shen and B. P. Sullivan, "Versatile Preparative Route to 5-Substituted-1,10-phenanthroline Ligands via 1,10Phenanthroline-5,6-epoxide," Inorganic Chemistry, Vol. 34, No. 25, 1995, pp. 6235-6236. doi:10.1021/ic00129a003

[4] M. A. Akbar, M. H. Mirza, Ai. L. Tan, L. K. Wei and P. V. Bernhardt, "The Preparation and Characterization of Seven-Coordinated Tin (IV) Complexes of the 2,6-Diacetylpyridine Schiff Bases of S-Alkyl/Aryl-dithiocarbazates and the X-Ray Crystal Structure of the [Sn (dapsme)I2] Complex (Dapsme=Doubly Protonated form 
of the 2,6-Diacetylpyridine Schiff Bases of S-Methyldithiocarbazate)," Polyhedron, Vol. 23, No. 11, 2004, pp. 2037-2043. doi:10.1016/j.poly.2004.05.010

[5] S. Kumar, D. N. Dhar and P. N. Saxena, "Applications of Metal Complexes of Schiff Bases-A Review," Journal of Scientific and Industrial Research, Vol. 68, No. 3, 2009, pp. 181-187.

[6] F. C. Kerbs, "Functionalization of the Hinge Region in Receptor Molecules for Explosive Detection," Tetrahedron Letters, Vol. 44, No. 35, 2003, pp. 6643-6646. doi:10.1016/S0040-4039(03)01683-6

[7] H. Jiang, W. Sun and R. Zheng, "Synthesis and Magnetic Properties of Novel Containing 1,10-Phenanthroline Polymeric Complexes," European Polymer Journal, Vol. 42, No. 2, 2006, pp. 425-433. doi:10.1016/j.eurpolymj.2005.07.003

[8] H.-W. Kuai, X.-C. Cheng and X.-H. Zhu, "Syntheses, Structures, and Properties of a Series of New Assembled Metal Complexes with 4-(Benzimidazol-1-ylmethyl)benzoate," Journal of Coordination Chemistry, Vol. 66, No. 1, 2013, pp. 28-41. doi:10.1080/00958972.2012.746458

[9] M. Andruh, "Compartmental Schiff-Base Ligands-A Rich Library of Tectons in Desgning Magnetic and Luminescent Materials," Chemical Communications, Vol. 47, No. 11, 2011, pp. 3025-3042. doi:10.1039/c0cc04506c

[10] N. S. Kozlov, G. P. Korotyshova, N. G. Rozhkova and E. I. Andreeva, "Synthesis of Fluorine-Containing Aromatic Azomethines with a Pesticidal Activity," Vesti Akad Navuk USSR Ser Khim Navuk, Vol. 2, 1986, p. 54.

[11] J. Akther, S. Lindeman and M. R. Karim, "2,9-Bis(1,3benzothia-zol-2-yl)-1,10-phenanthroline Dichloro-Methane Disolvate," Acta Crystallographica, Vol. 64, 2008, Article ID: 01836.
[12] S. Thiele, et al., "Modulation in Selectivity and Allosteric Properties of Small-Molecule Ligands for CC-Chemokine Receptors," Journal of Medicinal Chemistry, Vol. 58, No. 18, 2012, pp. 8164-8177. doi:10.1021/jm301121j

[13] F. W. Lewis, et al., "Highly Efficient Separation of Actinides from Lanthanides by a Phenanthroline-Derived BisTriazine Ligand," Journal of the American Chemical Society, Vol. 133, No. 33, 2011, pp. 13093-13102. doi: $10.1021 / \mathrm{ja} 203378 \mathrm{~m}$

[14] C. Musetti, et al., "Metal Ion-Mediated Assembly of Effective Phenanthroline-Based G-Quadruplex Ligands," Dalton Transactions, Vol. 19, 2009, pp. 3657-3660. doi:10.1039/b904630p

[15] M. T. H. Tarafder, K. B. Chew, K. A. Crouse, A. M. Ali, B. M. Yamin and H. K. Fun, "Synthesis and Characterization of $\mathrm{Cu}(\mathrm{II}), \mathrm{Ni}$ (II) and $\mathrm{Zn}$ (II) Metal Complexes of Bidentate NS Isomeric Schiff Bases Derived from S-Methyldithiocarbazate (SMDTC): Bioactivity of the Bidentate NS Isomeric Schiff Bases, Some of Their $\mathrm{Cu}(\mathrm{II}), \mathrm{Ni}(\mathrm{II})$ and $\mathrm{Zn}(\mathrm{II})$ Complexes and the X-Ray Structure of the Bis[S-methyl- $\beta$-N-(2-furylmethyl) Methylenedithiocarbazato]zinc(II) Complex," Polyhedron, Vol. 21, No. 27-28, 2002, pp. 2683-2690. doi:10.1016/S0277-5387(02)01285-8

[16] CrystalClear: Rigaku Corporation, "CrystalClear Software User's Guide, Molecular Structure Corporation," Rigaku Corporation, 1999, pp. 1718-1725.

[17] G. M. Sheldrick, "Program for the Solution and Refinement of Crystal Structures," University of Göttingen, Göttingen, 1997.

[18] L. J. Farrugia, "WinGX Suite for Small-Molecule SingleCrystal Crystallography," Journal of Applied Crystallography, Vol. 32, 1999, pp. 837-838. doi: $10.1107 / \mathrm{S} 0021889899006020$ 